\title{
Autonomy, Critical Thinking and Listening Comprehension Ability of Iranian EFL Learners
}

\author{
Atefeh Elekaei (Corresponding author) \\ Young Researchers and Elite Club, Qazvin Branch, Islamic Azad University, Qazvin, Iran \\ E-mail: atefehelekaei@yahoo.com \\ Sajad Faramarzi \\ Young Researchers and Elite Club, Karaj Branch, Islamic Azad University, Karaj, Iran \\ E-mail: sajadfaramarzijj@gmail.com \\ Hossein Heidari Tabrizi \\ Department of English, Isfahan (Khorasgan) Branch, Islamic Azad University, Isfahan, Iran \\ E-mail: heidaritabrizi@gmail.com
}

\author{
Received: 05-09-2015 \\ Accepted: 04-12-2015 \\ Advance Access Published: December 2015 \\ Published: 01-03-2016 \\ doi:10.7575/aiac.ijalel.v.5n.2p.40 \\ URL: http://dx.doi.org/10.7575/aiac.ijalel.v.5n.2p.40
}

\begin{abstract}
The present study was conducted in order to identify the relationship among autonomy, critical thinking ability and listening comprehension ability of Iranian EFL learners. 114 male and female learners learning English as a foreign language participated in the present study. The obtained data were analyzed using Pearson correlation coefficient and One-Way ANOVA. The results of the present study indicated that there was a significant positive relationship between autonomy and critical thinking ability of learners. Moreover, the results of One-Way ANOVA revealed that learners with high autonomy level had the best listening comprehension ability. Furthermore, learners with high critical thinking ability had high listening comprehension ability.
\end{abstract}

Keywords: autonomy, critical thinking ability, listening comprehension ability, Iranian EFL learners

\section{Introduction}

Nowadays, listening comprehension has attracted the focus of more researchers. As Rost (2002) believes, listening comprehension is an inferential process. Moreover, the main function of education in educational setting is learning to think (Dewey, 1933) and critical thinking ability is one internal factor that affects the process of learning (Chamot, 1995).Goss (1982) mentions that listening comprehension is a mental process and listeners try to create meaning out of the information they receive from the speakers. Moreover, critical thinking which includes assessment is a strongminded decision utilized in examination, deduction, estimation as well as understanding (Astleitner, 2002).

At the same time, learner autonomy has become more important recently and more learners try to be autonomous as learners are the main parts of language teaching as well as learning. As O'Donnell, Reeve and Smith (2012) points out, autonomy is one of the internal factors that help learners experience being autonomous, competent as well as related to others and as $\mathrm{Ku}(2009)$ remarks, promoting learner autonomy needs take advantage of learner's potential for learning through critical reflection. Also, Wagner (1997) believes that people cannot develop knowledge or skills in various areas without engaging in the process of thinking.

Although many researchers have investigated listening comprehension ability, critical thinking ability and autonomy (Kato, 2005; Modirkhamene, and Rezazade, 2012; Myers and Dyer, 2006; Nation and Meara, 2002; Yahong, 2009), few have examined research on the relationship among them. Therefore, the present study aims to find answers to the following questions:

1. Are there any significant relationships between autonomy and critical thinking ability of Iranian EFL learners?

2. Does autonomy level significantly influence listening comprehension ability of Iranian EFL learners?

3. Does critical thinking ability level significantly influence listening comprehension ability of Iranian EFL learners?

\section{Literature Review}

\subsection{Learner Autonomy}

Learner autonomy is the ability of learners to make their own decisions rather than being influenced by someone else. Dickinson (1995) defines autonomy as attitudes of learners towards learning through which learners practice to take responsibility for learning. Moreover, Breeze (2000) argues that learner autonomy is an inquiry of attitudes and experience. Similarly, Little (1995) mentions that autonomy is a matter of learning as well as learning how to learn in 
formal educational settings. Among many definitions which were suggested by many researchers, Benson and Voller (1997) believe that autonomy includes five main categories including sets of skills which can be learned and applied in self-directed learning, inborn capacities which are supposed by institutional education, the rights of learners in order to determine the direction of their own learning, situations in which learners study on their own and exercises of learners' responsibility for their own learning.

Learners need to be autonomous since teachers are not always available to guide and help them. Hence, Nation and Macalister (2010) remark that, learners should have the capacity to examine 'how to learn a language and how to monitor and be aware of their learning, so that they can become effective and independent language learners' (p. 38). Thanasoulas (2000) points out that factors such as learner's motivation, attitude, needs, learning styles, language learning strategies and language awareness are important in promoting learner autonomy.

Many researchers (Dam, 1995; Holec, 1981; Little, 1991) believe that autonomy has a great role in education. They agree that learners who have higher degrees of autonomy are more motivated to learn and achieve knowledge and also have higher senses of self-efficacy in their learning.

Arkoç (2008) conducted a study to find the effect of autonomy on listening comprehension success. Results of the study revealed that there was no significant relationship between autonomous learning and listening comprehension ability of the learners.

Tabatabaei and Parsafar (2012) examined the effect of learners' self-directed learning on their critical thinking ability. Based on the results, self-directed learning significantly affected learners' critical thinking ability.

Fahim and Haghighi (2014) examined the relationship between EFL learners' academic self-regulation and their critical thinking ability. 90 EFL learners participated in the study. Results indicated that there was a significant positive relationship between self-regulation and critical thinking ability of the learners.

Nosratinia and Zaker (2013) conducted a study in order to investigate the relationship between critical thinking ability and autonomy of 182 Iranian male and female learners. The results of the study revealed that there was a significant and positive relationship between critical thinking and autonomy of the participants.

\subsection{Listening Comprehension}

Clearly, listening plays an important role in communication and as Morley (1999) and Scarcella and Oxford (1992) believe, listening is the main and common employed speech ability. Some researchers (Coakley \& Wolvin, 1997; Truesdale, 1990) pointed out that listening comprehension ability is more important than reading skills in educational setting. According to Rost (2002), understanding spoken language is an inferential process and what the speaker says can be understood when sensitive imageries are opened to what the speakers say. Rost (2002) proposes four categories for listening. Listening is receptive when it is what the speaker actually says, constructive when it creates and signifies meaning, collaborative when it negotiates meaning with the speaker and listener and transformative when it creates meaning through participation and imagination.

A number of studies (Liu, 2008; ModirKhamene and Rezazade, 2012; Wang and Li, 2012) have been done on listening comprehension ability. Liu (2008) examined the relationship among listening strategy use, listening proficiency levels and learning styles. Based on the results, a significant difference was found between the strategy use and the attainment level. Also, there was a significant relationship between learning styles and listening strategy use.

Wang and $\mathrm{Li}$ (2012) conducted a study in order to investigate the relationship between listening comprehension strategies and autonomous learning. The results showed that autonomous learning significantly affected listening comprehension ability of the learners.

ModirKhamene and Rezazade (2012) considered the relationship between listening comprehension and Gardner's eight intelligence types. 75 intermediate participants participated in the study. Based on the results, visual and interpersonal intelligences had significant positive relationships with listening comprehension of the participants.

Hamouda (2013) examined the problems of listening of 60 students studying English in Qassim University who had listening course. The results of the study revealed any problems including pronunciation, different accent of speakers, speed of speech, inadequate vocabulary, lack of attentiveness, nervousness and bad quality of recording.

Alizahed, Jahandar and Khodabandehlou (2013) investigated the relationship between learners' critical thinking ability and their selected strategies of listening skills and the effect of gender on them. The results revealed that critical thinking ability significantly affected choosing listening strategies. However, there was not a significant relationship between gender and selected strategies of learners for listening comprehension through critical thinking ability.

Kasmani and Davoudy (2013) investigated the effect of using audio CDs on reading comprehension of 200 preintermediate learners. Results revealed a positive relationship between simultaneous reading and listening comprehension of the participants.

Azadi, Zare and Khorram (2015) examined the relationship between learners' critical thinking ability and their listening strategies. The results revealed a significant and positive relationship between them. Also, meta-cognitive strategies were the most strategies used by learners. 
Ennis (1987) defines critical thinking as a coherent as well as thoughtful process which connects skills and dispositions. Kress (1985) believes that critical thinking is a language itself and defines critical thinking ability as a social practice. Moreover, Astleitner (2002) defines critical thinking ability as 'a purposeful, self-regulatory judgment which results in interpretation, analysis evaluation, and inference, as well as explanations of evidential, conceptual, methodological or contextual consideration upon which the judgment is based' (p. 53).

Brookfield (1987) states two interrelated processes for critical thinking, 'identifying and challenging assumptions, and imagining and exploring others' (p. 229). Schafersman (1991) believes that education must engage 'how to think' in addition to 'what to think'.

Myers and Dyer (2006) examined the effect of 135 students' learning style on their critical thinking ability. Based on the results, no differences were found between critical thinking abilities of male and female. Moreover, it was found that students with fixed theoretical and chronological learning styles had significant critical thinking scores.

Birjandi and Bagherkazemi (2010) investigated the relationship between EFL teachers' critical thinking skill and their student-evaluated professional success. The results indicated a significant relationship between them. Moreover, three of the five aspects of critical thinking which are 'drawing inferences', 'interpreting evidence', and 'evaluating arguments' were significantly and positively correlated with SIET scores.

Fahim and Sa'eepour (2011) investigated the effect of teaching critical thinking skills on reading comprehension ability on the one hand, and the effect of applying debate on critical thinking of EFL learners on the other hand. Based on the results, there were significant differences among learner's reading comprehension scores. However, the differences among learners' critical thinking scores were not significant. Also, Hashemi and Zabihi (2012) conducted a study in order to examine the relationship between learners' critical thinking ability and their receptive English language proficiency skills. Based on the results, a significant and positive relationship was found.

Hosseini, Khodaei, Sarfallah and Dolatabadi (2012) investigated the relationship among reading comprehension, critical thinking and reading strategies of 70 English university students. Results showed that there was a significant positive relationship between participants' critical thinking ability and their reading comprehension as well as participants' critical thinking ability and reading strategy use. Moreover, cognitive and affective strategies and critical thinking ability were the best predictors of reading.

Nosratinia, Asiabar and Sarabchian (2014) investigated the relationship between EFL learners' language learning strategy use and their critical thinking ability. Results revealed that there was a significant and positive relationship between learners' use of language learning strategies and their critical thinking ability. In addition, memory strategy was the best predictor of critical thinking ability of learners.

Fahim and Bolghari (2014) examined the relationship between learners' critical thinking ability and their learning styles. Results showed that there was a significant and positive relationship between learner's critical thinking ability and all learning style dimensions. In addition, results revealed that Abstract Conceptualization dimension of learning style was the best predictor of learners' critical thinking ability.

Fahim and Afshari (2014) investigated the relationship between critical thinking of Iranian learners and reading strategies regarding goals and objectives in the process of curriculum development. Based on the results, there was not a relationship between learners' critical thinking ability and their overall use of reading strategies in the process of curriculum development.

Barghi and Zangoei (2014) conducted a study to examine the relationship between learners' learning style preferences and their critical thinking ability. The results revealed that there was a significant relationship between learners' critical thinking ability and their communicative learning style.

Fahim and Hoominian (2014) investigated the relationship between critical thinking ability and reading strategies of Iranian EFL learners. The results showed that there was no correlation between critical thinking ability of learners and their overall use of reading strategies. Moreover, meta-cognitive and cognitive strategies were the most frequents strategies used by learners.

\section{Method}

3.1 Participants

125 Iranian male and female learners learning English as a foreign language at Andisheh-Nou Language School in Qazvin participated in the present study. After taking the results of the Michigan Test of English Language Proficiency into account, the number of the participants was reduced to 114. The learners' age ranged from 16 to 30 .

\subsection{Instruments}

The following instruments were used in order to answer the research questions:

\section{A Proficiency Test}

2. An IELTS Listening Comprehension Test

3. An Autonomy Questionnaire

4. A Critical Thinking Ability Questionnaire 
First, a proficiency test (The Michigan English Language Proficiency Test) was administered in order to homogenize the participants. Second, an IELTS listening comprehension test was administered. Third, a learner autonomy questionnaire including 52 items was given to the students in order to investigate the participants' level of autonomy. The learner autonomy questionnaire was designed and validated by Spratt, Humphreys, and Chan (2002). The questionnaire included four sections examining the participants' view of their responsibilities and those of their teachers (13 items), the participants' confidence in their ability to operate autonomously (11 items), participants' level of motivation to learn English (1 item) and participants' practice of autonomous learning inside and outside of classroom (27 items). The questionnaire was in the form of a Likert scale from 'not at all' to 'completely' in section one ('not at all', 'a little', 'some', 'mainly' and 'completely'), from 'very poor' to 'very good' in section two, setting 5 to 1 beside the first to the last choices in section three and from 'never' to 'often' in section four ('never', 'rarely', 'sometimes', and 'often').

Fourth, a critical thinking ability questionnaire which was developed by Honey (2000) was administered. The critical thinking ability questionnaire aims at investigating the comprehension, analysis and evaluation skills of the participants. It is a 5-point Likert scale questionnaire ranging from 1 (never) to 5 (always) including 30 items examining the participants' abilities in summarizing, paraphrasing, questioning, note-taking, classifying, researching, discussing, comparing and contrasting, inductive and deductive reasoning, outlining, distinguishing, inferencing and synthesizing. The Persian version of the questionnaire which was translated and validated by Naeini (2005) was utilized in the present study.

\subsection{Procedures}

In order to achieve the purpose of the present study, the following procedures were followed. First, a general proficiency test was administered in order to make sure of the proficiency level of the students. The participants had one hour to answer the questions. Second, an IELTS listening comprehension test was administered in order to investigate the listening comprehension ability of the participants which took 40 minutes. Third, the participants were asked to complete an autonomy questionnaire and a critical thinking ability questionnaire. They had 1 hour to complete these two questionnaires.

The scores of the participants on the general proficiency test were summarized. The scores of those who achieved more than one standard deviation away from (above or below) the mean were excluded from all the subsequent analyses. Then, the obtained data were analyzed for further statistical analyses.

\subsection{Data Analysis}

In order to analyze the data and to answer the research question number one, that is the relationship between autonomy and critical thinking ability of Iranian EFL learners, one Pearson Correlation procedure was used. Then, to answer the research questions number two and three, that is the effect of participants' autonomy level on their listening comprehension ability as well as the effect of critical thinking ability level of the participants on their listening comprehension ability, two one-way ANOVA procedures were used.

\section{Results}

\subsection{Investigation of the First Research Question}

The first research question sought to investigate the relationship between autonomy and critical thinking ability of Iranian EFL learners. Therefore, a correlation procedure was run to answer this question. Table 1 presents the results of the correlation procedure for autonomy and critical thinking ability of learners.

Table 1. Correlation between Autonomy and Critical Thinking Ability of Iranian EFL Learners

\begin{tabular}{cccc}
\hline & & Autonomy & $\begin{array}{c}\text { Critical Thinking } \\
\text { Ability }\end{array}$ \\
\hline \multirow{3}{*}{ Autonomy } & Pearson Correlation & 1 & $.986^{* *}$ \\
& Sig. (2-tailed) & & .000 \\
$\mathrm{~N}$ & 114 & 114 \\
\hline
\end{tabular}

As Table 1 shows, there is a significant relationship between autonomy and critical thinking ability of Iranian EFL learners $(\mathrm{r}=.986, \mathrm{p}<.01)$.

\subsection{Investigation of the Second Research Question}

The second research question sought to see whether autonomy influences Iranian EFL learners' listening comprehension ability. Therefore, participants were divided into three equal groups of high, medium, and low level of autonomy based on their scores of the autonomy questionnaire. One-Way ANOVA was run to examine the effect of autonomy level on the listening comprehension ability of learners. Table 2 shows the descriptive and test statistics. Based on Table 2, the high autonomy group has the highest mean $($ mean $=70.42)$, followed by the medium autonomy group $($ mean $=48.53)$, and the low autonomy group (mean $=29.32)$. Moreover, F-value is statistically significant $(\mathrm{F}=588.293, \mathrm{p}<.01)$. Therefore, the differences among three autonomy groups in listening comprehension ability are significant. 
Table 2. Descriptive and Test Statistics for the ANOVA on Autonomy and Listening Comprehension Ability of Iranian EFL Learners

\begin{tabular}{cccccc}
\hline & N & Mean & $\begin{array}{c}\text { Std. } \\
\text { Deviation }\end{array}$ & \multicolumn{2}{c}{$\begin{array}{c}\text { 95\% Confidence Interval for } \\
\text { Mean }\end{array}$} \\
\cline { 5 - 6 } & & & 5.160 & 68.72 & 72.12 \\
\hline High & 38 & 70.42 & 4.735 & 46.97 & 50.08 \\
Mid & 38 & 48.53 & 5.738 & 27.43 & 31.20 \\
Low & 38 & 29.32 & 17.645 & 46.15 & 52.70 \\
Total & 114 & 49.42 & $\mathrm{~F}$ & Sig $=.000$ \\
\hline
\end{tabular}

To locate the differences among the three autonomy groups, the post hoc Scheffe test procedure was run, presenting the following results:

Table 3. Post Hoc Multiple Comparisons of Autonomy and Listening Comprehension Ability of Iranian EFL Learners

\begin{tabular}{llllll}
\hline (I) Autonomy & (J) Autonomy & Mean & Sig. & \multicolumn{2}{l}{$95 \%$ Confidence Interval } \\
\cline { 4 - 5 } Groups & Groups & Difference (I-J) & & $\begin{array}{l}\text { Lower } \\
\text { Bound }\end{array}$ & Upper Bound \\
& & & .000 & 18.92 & 24.87 \\
High & Mid & $21.895^{*}$ & .000 & 38.13 & 44.08 \\
High & Low & $41.105^{*}$ & .000 & 16.24 & 22.19 \\
Mid & Low & $19.211^{*}$ & & \\
\hline
\end{tabular}

*. The mean difference is significant at the 0.05 level.

Figure 1 shows the differences among the three autonomy groups conspicuously.

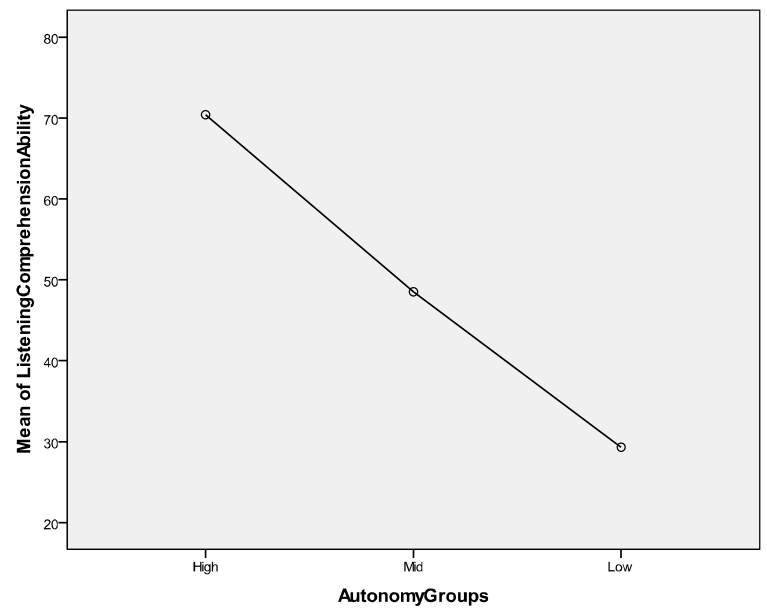

Figure 1. The Differences among the Three Autonomy Groups and Listening Comprehension Ability of Iranian EFL Learners

\subsection{Investigation of the Third Research Question}

The third research question sought to see whether critical thinking ability influences Iranian EFL learners' listening comprehension ability. Therefore, participants were divided into three equal groups of high, medium, and low level of critical thinking ability based on their scores of the critical thinking questionnaire. One-Way ANOVA was run to examine the effect of critical thinking ability level on the listening comprehension ability of learners. Table 4 shows the descriptive and test statistics. Based on table 2, the high critical thinking ability group has the highest mean (mean $=$ 70.58), followed by the medium critical thinking ability group (mean $=48.42$ ), and the low critical thinking ability group $($ mean $=28.58)$. Moreover, $F$-value is statistically significant $(\mathrm{F}=529.015, \mathrm{p}<.01)$. Therefore, the differences among three critical thinking ability groups in listening comprehension ability are significant. 
Table 4. Descriptive and Test Statistics for the ANOVA on Critical thinking and Listening Comprehension Ability of Iranian EFL Learners

\begin{tabular}{cccccc}
\hline & N & Mean & $\begin{array}{c}\text { Std. } \\
\text { Deviation }\end{array}$ & \multicolumn{2}{c}{$\begin{array}{c}\text { 95\% Confidence Interval for } \\
\text { Mean }\end{array}$} \\
\cline { 3 - 6 } & & & 5.480 & 68.78 & 72.38 \\
& & 70.58 & 5.054 & 46.76 & 50.08 \\
High & 38 & 48.42 & 6.289 & 26.51 & 30.65 \\
Mid & 38 & 28.58 & 18.112 & 45.83 & 52.55 \\
Total & 38 & 49.19 & \multicolumn{3}{c}{ Sig $=.000$} \\
\hline
\end{tabular}

To locate the differences among the three autonomy groups, the post hoc Scheffe test procedure was run, yielding the following results:

Table 5. Post Hoc Multiple Comparisons of Critical Thinking and Listening Comprehension Ability of Iranian EFL Learners

\begin{tabular}{|c|c|c|c|c|c|}
\hline \multirow{2}{*}{$\begin{array}{l}\text { (I) Critical Thinking } \\
\text { Ability Groups }\end{array}$} & \multirow{2}{*}{$\begin{array}{l}\text { (J) Critical Thinking } \\
\text { Ability Groups }\end{array}$} & \multirow{2}{*}{$\begin{array}{c}\text { Mean } \\
\text { Difference (I-J) }\end{array}$} & \multirow[t]{2}{*}{ Sig. } & \multicolumn{2}{|c|}{$95 \%$ Confidence Interval } \\
\hline & & & & $\begin{array}{l}\text { Lower } \\
\text { Bound }\end{array}$ & $\begin{array}{l}\text { Upper } \\
\text { Bound }\end{array}$ \\
\hline High & Mid & $22.158^{*}$ & .000 & 18.95 & 25.36 \\
\hline High & Low & $42.000^{*}$ & .000 & 38.79 & 45.21 \\
\hline Mid & Low & $19.842^{*}$ & .000 & 16.64 & 23.05 \\
\hline
\end{tabular}

*. The mean difference is significant at the 0.05 level.

Figure 2 shows the differences among the three autonomy groups clearly.

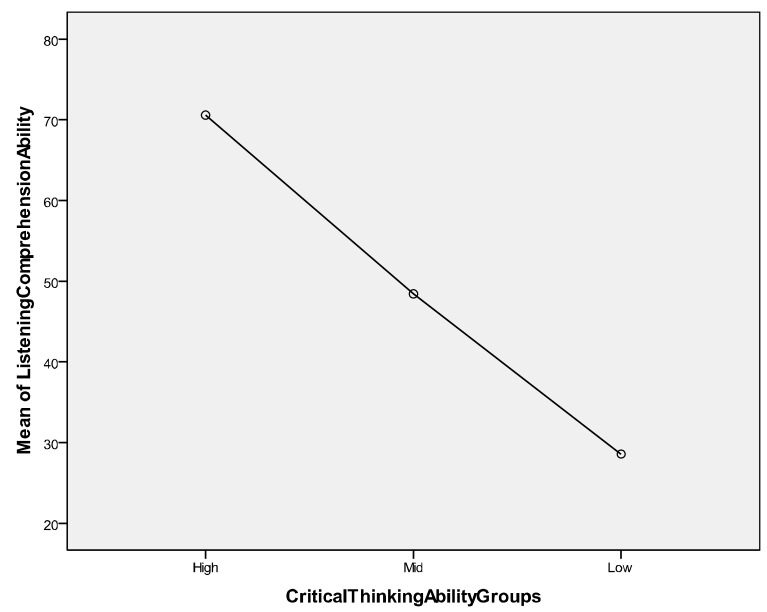

Figure 2. The Differences among the Three Critical thinking Ability Groups and Listening Comprehension Ability of Iranian EFL Learners

\section{Discussion}

The present study sought to investigate the relationship between autonomy and critical thinking ability of Iranian EFL learners, the effect of learners' autonomy level on learners' listening comprehension ability and the effect of learners' critical thinking ability on their listening comprehension ability. One of the findings of the present study was that there was a significant and positive relationship between learner autonomy and critical thinking ability of Iranian EFL learners. This finding is in line with a number of previous studies (Dam, 1995; Holec, 1981; Little, 1991) who found that learners who have higher degrees of autonomy are more motivated to learn and achieve knowledge and also have higher senses of self-efficacy in their learning.

Also, the findings of the present study support Tabatabaei and Parsafar's (2012) findings who found that self-directed learning significantly affected learners' critical thinking ability. Moreover, this finding is compatible with the study of Fahim and Haghighi (2014) who indicated that there was a significant positive relationship between self-regulation and critical thinking ability of the learners. The present study also supports the findings of Nosratinia and Zaker's (2013) 
study who reported that there was a significant and positive relationship between critical thinking and autonomy of the participants. . In addition, the present study is in line with the study which has been conducted by Birjandi and Bagherkhazemi (2010). They found that there was a considerable relationship between critical thinking ability of the learners and their self-evaluated professional success.

The other finding of the present study was that autonomy level significantly affected listening comprehension ability of learners. In other words, learners with higher level of autonomy had better scores of listening comprehension. This finding is compatible with those of Wang and Li (2012), who found that autonomous learning significantly affected listening comprehension ability of the learners.

The other finding of the present study was that the level of critical thinking of learners significantly affected their listening comprehension results. In other words, learners with higher critical thinking ability had higher listening comprehension scores. This result is compatible with the results of a number of previous studies (Myers and Dyer, 2006; Nosratinia, Asiabar and Sarabchian, 2014). The results of the present study is compatible with Myers and Dyer (2006) who found a significant and positive relationship between critical thinking scores of students and their learning styles. This finding also is in line with the findings of Nosratinia, Asiabar and Sarabchian's (2014) study who found a positive relationship between critical thinking ability of the participants and their use of language learning strategies.

Moreover, the present study is compatible with studies of Barghi and Zangoei (2014) and Fahim and Bolghari (2014) who found significant relationships between learners' critical thinking ability and their communicative learning style, and between learner's critical thinking ability and all learning style dimensions, respectively. In addition, these findings lend support to those of Alizahed, Jahandar and Khodabandehlou (2013), who found that critical thinking ability significantly affected choosing listening strategies.

At the same time, the findings of the present study contradict a number of previous studies (Alizahed, Jahandar and Khodabandehlou, 2013; Fahim and Afshari, 2014; Fahim and Hoominian, 2014; Myers and Dyer, 2006). The findings of this study are in contrast with those of Myers and Dyer (2006) who found no significant relationship between gender and selected strategies for listening comprehension of students through critical thinking ability. The results of the present study also contradict the studies of Fahim and Afshari (2014) and Fahim and Hoominian (2014) who found no relationship between learners' critical thinking ability and their overall use of reading strategies. Moreover, the findings of this study are in contrast to those of Arkoç (2008) who found that there was no significant relationship between autonomous learning and listening comprehension ability of the learners.

\section{Conclusion}

The present study sought to investigate the relationship between autonomy and critical thinking ability of Iranian EFL learners, the effect of learners' autonomy level on learners' listening comprehension ability and the effect of learners' critical thinking ability on their listening comprehension ability. One of the findings of the present study was that there was a significant and positive relationship between learner autonomy and critical thinking ability of Iranian EFL learners.

The other finding of the present study was that autonomy level significantly affected listening comprehension ability of learners. In other words, learners with higher level of autonomy had better scores of listening comprehension. Moreover, the other finding of the present study was that the level of critical thinking of learners significantly affected their listening comprehension results. In other words, learners with higher critical thinking ability had higher listening comprehension scores.

\section{References}

Alizahed, H., Jahandar, Sh., \& Khodabandehlou, M. (2013). The relationship between the critical thinking and the learning strategies selected for listening by Iranian EFL learners at B.A. level. Indian Journal of Fundamental and Applied Life Sciences, 3(4), 189-195.

Arkoç, E. Ş. (2008). The impact of learner autonomy on the success of listening comprehension. Doctoral dissertation, Trakya University.

Astleitner, H. (2002). Teaching critical thinking online. Journal of Instructional Psychology, 29(2), 53-77.

Azadi, A. A., Zare, Z., \& Khorram, A. (2015). The relationship between the critical thinking ability and the listening strategies of Iranian EFL learners. International Journal of Educational Investigations, 2(6), 32-47.

Barghi, E., \& Zangoei, A. (2014). Learners' language learning style preferences and its relationship with their critical thinking ability in an Iranian EFL context. International Journal of Language Learning and Applied Linguistics World, 6(2), 269-280.

Benson, P., \& Voller, P. (1997). Autonomy and independence in language learning. New York: Addison Wesley Longman Limited.

Birjandi, P., \& Bagherkazemi, M. (2010). The relationship between Iranian EFL teachers' critical thinking ability and their professional success. English Language Teaching, 3(2), 135-145.

Breeze, R. (2002). Attitudes towards learner autonomy among Spanish University students. Atlantis, 24(2), 23-36.

Brookfield, S. (1987). Developing critical thinkers. Milton Keyes: Open University Press. 
Chamot, A. (1995). Creating a community of thinkers in the ESL/EFL classroom. TESOL Matters, 5(5), 1-16.

Coakley, C., \& Wolvin, A. (1997). Listening in the instructive situation, listening in everyday life: A personal and professional approach. Lanham, MD: University Press of America.

Dam, L. (1995). Learner autonomy 3: From theory to classroom practice. Dublin: Authentik.

Dewey, J. (1933). How to think: Restatement of the relation of reflective thinking to the educational process. Lexington, MA: D. C. Health.

Dickinson, L. (1995). Autonomy and motivation: A literature review. System, 23(2), 165-174.

Ennis, R. (1996). Critical thinking appraisal. Journal of Theory into Practice, 32(3), 179-186.

Fahim, M., \& Afshari, A. (2014). The relationship between critical thinking and reading strategies regarding goals and objectives in the process of curriculum development. International Journal for teachers of English, 4(4), 62-82.

Fahim, M., \& Bolghari, M. S. (2014). The relationship between critical thinking ability of Iranian EFL learners and their learning styles. International Journal of Language Learning and Applied Linguistics World, 5(3), 54-69.

Fahim, M., \& Haghighi, M. (2014). The relationship between critical thinking ability of Iranian EFL learners and their academic self-regulation. International Journal of Language Learning and Applied Linguistics World, 5(3), $390-400$.

Fahim, M., \& Hoominian, Z. (2014). The relationship between critical thinking ability and reading strategies used by Iranian EFL learners. ELT Voices, 4(6), 70-78.

Fahim, M., \& Sa'eepour, M. (2011). The impact of teaching critical thinking skills on reading comprehension of Iranian EFL learners. Journal of Language Teaching and Research, 2(4), 867-874.

Goss, B. (1982). Listening as information processing. Journal of Communication Quarterly, 30, 304-307.

Hamouda, A. (2013). An investigation of listening comprehension problems encountered by Saudi students in the EL listening classroom. International Journal of Academic Research in Progressive Education and Development, 2(2), 113-155.

Hashemi, M. R., \& Zabihi, R. (2012) Does critical thinking enhance EFL learners' receptive skills? Journal of Language Teaching Research, 3(1), 172-179.

Holec, H. (1981). Autonomy and foreign language learning. Oxford: Pergamon.

Hosseini, E., Khodaei, F. B, Sarfallah, S. \& Dolatabadi, H. R. (2012). Exploring the relationship between critical thinking, reading comprehension and reading strategies of English university students. Journal of World Applied Sciences, 17(10), 1356-1364

Kasmani, M. B., \& Davoudy, S. M. (2013). The impact of using audio CD on reading comprehension of preintermediate Iranian learners. Journal of Social Sciences \& Humanities, 2(1), 39-50.

Kato, S. (2005). How language learning strategies affect English proficiency in Japanese university students. Journal of the Faculty of Human Studies Bunkyo Gakuin University, 7(1), 239-262.

$\mathrm{Ku}$, Y. L. K. (2009). Assessing students' critical thinking performance: Urging for measurements using multi-response format. Thinking Skills and Creativity, 4, 70-76.

Little, D. (1991). Learner autonomy 1: definitions, issues, and problems. Dublin: Authentik.

Little, D. (1995). Learning as dialogue: The dependence of learner autonomy on teacher autonomy. System, 23(2), 175182.

Liu, H. J. (2008). A study of the interrelationship between listening strategy use, listening proficiency levels, and learning style. Journal of RARECLS, 5, 84-104.

Modirkhamene, S., \& Rezazade, E. (2012). The predicting power of Gardner's eight gates of intelligences explored in listening comprehension. Journal of World Applied Sciences, 18(4), 486-492.

Morley, J. (1999). Present point of views on improving aural comprehension. Retrieved from http://www.eslmag.com/MorleyAuralStory.html

Myers, B. E., \& Dyer, J. E. (2006). The consequences of student learning style on critical thinking skill. Journal of Agricultural Education, 4(7), 43-52.

Naeini, J. (2005). The effect of collaborative learning on critical thinking of Iranian EFL learners (Unpublished master's thesis). Islamic Azad University at Central Tehran, Iran.

Nation, I. S. P., \& Macalister, J. (2010). Language curriculum design. New York: Routledge.

Nation, I. S. P., \& Meara, P. (2002). Vocabulary. In N. Schmitt (Ed.), An introduction to applied linguistics (pp.35-54). London: Arnold.

Nosratinia, M., Asiabar, M. G., \& Sarabchian, E. (2014). The relationship between Iranian EFL learners' language learning strategies and critical thinking. International Journal of Language and Applied Linguistics World, 5(2), 335345. 
Nosratinia, M., \& Zaker, A. (2013). Autonomous learning and critical thinking: Inspecting the association among EFL learners. Paper presented at the First national Conference on Teaching English, Literature, and translation, Shiraz University, Shiraz, Iran. Retrieved from http://www.civilica.com/Paper-TELT01-TELT01_226.html

O'Donnell, A., Reeve, J., \& Smith, J. (2012). Educational Psychology: Reflection for action. Hoboken, NJ: Wiley.

Rost, M. (2002). Education and exploration listening. London, UK: Longman.

Scarcella, R. C., \& Oxford, R. L. (1992). The tapestry of language learning: The individual in the communicative classroom. Boston, MA: Heinle \& Heinle.

Schafersman, S. D. (1991). An introduction to critical thinking. retrieved June 25, 2015 from www.freeenquiry/criticalthinking.html

Tabatabaei, O., \& Parsafar, S. M. (2012). The effect of self-directed learning on critical thinking of Iranian EFL learners. Journal of Educational and Social Research, 2(2), 55-64.

Thanasoulas, D. (2000). Autonomy and learning: An epistemological approach. Applies Semiotics, 4(10), $115-131$.

Truesdale, S. P. (1990). Whole-body listening: Developing dynamic auditory skills. Journal of Language and Hearing Services in Schools, 21, 183-184.

Wagner, R. K. (1997). Intelligence, training, and employment. American Psychologist, 52(10), 1059-1069.

Wang, L., \& Li, Y. M. (2012). An Empirical Study of Listening Comprehension Strategies in Autonomous Learning Environment. Sino-US English Teaching, 9(11), 1695-1701.

Yahong, L. (2009). How can I help my students promote learner-autonomy in English language learning? Educational Journal of Living theories, 2(3), 365-398. 